\author{
Marquette University \\ e-Publications@Marquette
}

Biomedical Engineering Faculty Research and

Publications

Biomedical Engineering, Department of

$10-2012$

\title{
Design and Validation of Bending Test Method for Characterization of Miniature Pediatric Cortical Bone Specimens
}

Carolyne Albert

Marquette University, carolyne.albert@marquette.edu

John Jameson

Marquette University

Gerald F. Harris

Marquette University, gerald.harris@marquette.edu

Follow this and additional works at: https://epublications.marquette.edu/bioengin_fac

Part of the Biomedical Engineering and Bioengineering Commons

\section{Recommended Citation}

Albert, Carolyne; Jameson, John; and Harris, Gerald F., "Design and Validation of Bending Test Method for Characterization of Miniature Pediatric Cortical Bone Specimens" (2012). Biomedical Engineering Faculty Research and Publications. 49.

https://epublications.marquette.edu/bioengin_fac/49 
Marquette University

e-Publications@Marquette

\section{Biomedical Engineering Faculty Research and Publications/College of} Engineering

This paper is NOT THE PUBLISHED VERSION; but the author's final, peer-reviewed manuscript. The published version may be accessed by following the link in the citation below.

Proceedings of the Institution of Mechanical Engineers, Part H: Journal of Engineering in Medicine, Vol. 227, No. 2 (February 1, 2013): 105-113. DOI. This article is (C) SAGE Publications and permission has been granted for this version to appear in e-Publications@Marquette. SAGE Publications does not grant permission for this article to be further copied/distributed or hosted elsewhere without the express permission from SAGE Publications.

\section{Design and Validation of Bending Test Method for Characterization of Miniature Pediatric Cortical Bone Specimens}

\section{Carolyne I. Albert}

Orthopaedic and Rehabilitation Engineering Center, Department of Biomedical Engineering, Marquette University, Milwaukee, WI

Shriners Hospitals for Children, Chicago, IL

John Jameson

Orthopaedic and Rehabilitation Engineering Center, Department of Biomedical Engineering, Marquette University, Milwaukee, WI

Gerald Harris

Orthopaedic and Rehabilitation Engineering Center, Department of Biomedical Engineering, Marquette University, Milwaukee, WI

Shriners Hospitals for Children, Chicago, IL 


\section{Abstract}

Osteogenesis imperfecta is a genetic disorder of bone fragility; however, the effects of this disorder on bone material properties are not well understood. No study has yet measured bone material strength in humans with osteogenesis imperfecta. Small bone specimens are often extracted during routine fracture surgeries in children with osteogenesis imperfecta. These specimens could provide valuable insight into the effects of osteogenesis imperfecta on bone material strength; however, their small size poses a challenge to their mechanical characterization. In this study, a validated miniature three-point bending test is described that enables measurement of the flexural material properties of pediatric cortical osteotomy specimens as small as $5 \mathrm{~mm}$ in length. This method was validated extensively using bovine bone, and the effect of span/depth aspect ratio ( 5 vs 6 ) on the measured flexural properties was examined. The method provided reasonable results for both Young's modulus and flexural strength in bovine bone. With a span/depth ratio of 6 , the median longitudinal modulus and flexural strength results were 16.1 (range: 14.4-19.3) GPa and 251 (range: 219-293) MPa, respectively. Finally, the pilot results from two osteotomy specimens from children with osteogenesis imperfecta are presented. These results provide the first measures of bone material strength in this patient population.

\section{Keywords}

Material properties, flexural, osteogenesis imperfecta, pediatric, bone

\section{Introduction}

Osteogenesis imperfecta (OI), or brittle bone disease, is a genetic disorder of bone fragility. This fragility is attributed to a combination of bone mass deficiency and compromised material properties. No data, however, is yet available to describe bone material strength in OI. Small bone fragments that are routinely extracted during fracture repair and corrective osteotomy procedures in young individuals with Ol could be useful for bone material characterization. Unfortunately, their small size, that is, often not more than $5 \mathrm{~mm}$ in length, renders these fragments unsuitable for typical mechanical characterization protocols, which require machined bone specimens that are a few centimeters long. ${ }^{1-5}$ In fact, few studies ${ }^{6,7}$ have explored the material behavior of pediatric bones in general, due to a scarcity of specimens available for testing. For this reason, a validated and appropriately sized test method enabling the measurement of material strength of miniature bone specimens could be useful in characterizing pediatric bones, such as those from children with brittle bones.

The characterization of Ol bone material and structural behavior can provide valuable insight toward improved care for children with this disorder. For example, finite element models have been developed to assess stress distribution and fracture risk in Ol during daily activities. ${ }^{8,9}$ These models could be useful in the development of treatment strategies to reduce fracture occurrence in individuals with Ol; however, the ability of these models to assess fracture risk remains hindered by a shortage of bone material property data in OI.

The most considerable challenge in mechanical characterization of pediatric osteotomy bone fragments is their small size, that is, often as small as $5 \mathrm{~mm}$ in length. Previously described techniques that are suitable for characterizing the mechanical properties of these miniature bone specimens include nanoindentation ${ }^{10-13}$ and micromechanical tests. ${ }^{14-16}$ Each of these techniques presents unique advantages and limitations.

During nanoindentation, a diamond-tip indenter is compressed into the surface of a polished specimen to measure local material properties, specifically, Young's modulus and hardness. The small scale of the indents, that is, typically a few hundred nanometers deep and a few microns wide, ${ }^{11,13,17}$ enables measurement of bone material properties within osteonal bone or individual trabeculae. Nonetheless, nanoindentation provides local measurements that vary considerably within a single specimen, ${ }^{18-21}$ and it does not offer a direct measure of material strength. 
A few studies have characterized flexural bone material properties using "microspecimens" (e.g. machined beams $120 \mu \mathrm{m} \times 120 \mu \mathrm{m} \times 1.5 \mathrm{~mm}$ in size). ${ }^{14-16}$ The described approach could be suitable for testing miniature osteotomy specimens. These microspecimens, however, are thinner than the diameter of a typical single secondary osteon, and they are therefore too small to capture the heterogeneous microstructure and composition of cortical bone. Moreover, the elastic modulus estimates obtained for adult human cortical bone using microspecimens, that is, $5-7 \mathrm{GPa},{ }^{14-16}$ tend to be much lower than the generally accepted values, that is, typically 15-20 GPa. 4,22 The size-dependency of human cortical bone elastic modulus measurements in bending was examined for beam depths (thicknesses) between 100 and $1000 \mu \mathrm{m}$, with a fixed span/depth aspect ratio of 10. ${ }^{16} \mathrm{~A}$ beam depth of approximately $560 \mu \mathrm{m}$ or greater provided a more or less constant modulus result of $15 \mathrm{GPa}$, whereas this measure decreased for beam depths less than $320 \mu \mathrm{m}$. A depth of $560 \mu \mathrm{m}$ would be appropriate for characterizing pediatric osteotomy specimens. With this specimen depth, a span/depth aspect ratio of 10 would require a span length of $5.6 \mathrm{~mm}$. Unfortunately, the surgical pediatric bone specimens that have been collected to date are often not greater than $5 \mathrm{~mm}$ in length; therefore, a maximum span length of $4 \mathrm{~mm}$ would be more appropriate for their characterization.

The objectives of this study are to describe a validated three-point bending test method suitable for measurement of the elastic modulus, yield stress, yield strain, and flexural strength, of small cortical osteotomy specimens obtained by routine surgery. The validation of the test method was performed with 39 beam specimens of bovine bone having two span/depth aspect ratios, 5 and 6 , and two orientations, that is, parallel and perpendicular to the long bone axis. The method was further validated with acrylic beam specimens. Finally, the described method was used to measure flexural bone material properties of cortical osteotomy specimens obtained from two children with Ol.

\section{Methods}

A three-point bending apparatus was designed to characterize the mechanical properties of miniature beams of cortical bone, approximately $5 \mathrm{~mm}$ in length. The potential sources of error were investigated carefully, in light of the small scale of the specimens and that of their maximum deflections during testing. A multistage approach was taken to validate the test setup, including validating load and deflection measurement, identifying and minimizing potential sources of experimental error, and assessing the effectiveness of the setup in measuring the modulus of elasticity $(E)$, yield strength $\left(\sigma_{y}\right)$, yield strain $\left(\varepsilon_{y}\right)$, and flexural strength $\left(\sigma_{f m}\right)$ of bone specimens.

\section{Jig design and testing system}

A custom-designed, three-point bending jig was built for this study (Figure 1). The loading nose and supports consisted of 1/16-in $(1.6 \mathrm{~mm})$ diameter stainless steel pins that were fixed into grooves machined in upper and lower aluminum platens using cyanoacrylate. A constant bottom span length $(L)$ of $4 \mathrm{~mm}$ (actual measurement $3.973 \mathrm{~mm}$ ) was chosen to accommodate the length of pediatric osteotomy specimens that were collected as part of another study. The jig was mounted onto an electromechanical testing system (Model 3345; Instron ${ }^{\circ}$, Norwood, MA) with a 50-N capacity load cell (Model 2519-102; Instron).
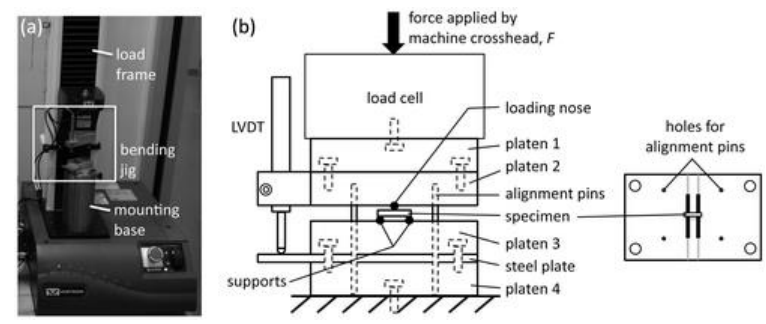

Figure 1. Diagram of three-point bending test setup. The three-point bending jig was mounted on an electromechanical materials testing machine, and the upper and lower platens were aligned using four dowel 
pins. Deflection was measured with an externally mounted LVDT. (a) Front view of the three-point bending test assembly (not drawn to scale). (b) Top view of the lower platen showing the bottom two rollers and the location of the four alignment pins.

The following potential sources of experimental error were identified: load measurement error, displacement measurement error, and misalignment between the loading nose and supports. Special care was taken to address these sources of error as follows:

a. Misalignment between the loading nose and supports: The top and bottom platens were aligned using four stainless steel dowel pins 1/16-in $(1.6 \mathrm{~mm}$ ) diameter, which were removed prior to testing (Figure 1). These alignment pins helped to ensure that the loading nose was parallel to and centered between the supports for a symmetrical loading configuration.

b. Load measurement error: The load cell calibration was verified using calibrated weights (Christian Becker Inc., New York). The slope of load measured versus load applied was $0.9999\left(R^{2}=1.0\right)$, indicating a load measurement error of approximately $0.01 \%$.

c. Displacement measurement error: With the electromechanical testing system (Model 3345; Instron ${ }^{\circledR}$ ), crosshead displacement is measured by a built-in encoder. The displacement measured by the built-in encoder provides a combined measure of beam specimen deflection and deformation occurring within the load frame, load cell, mounting base, and three-point bending jig, that is, the loading nose, supports, and platens (Figure 1). Thus, the use of the encoder displacement as a measure of midspan beam deflection would result in compounded errors from each of these components. To reduce this source of error, an external linear variable differential transformer (LVDT; Model 2601; Instron ${ }^{\circledR}$ ) was incorporated in the jig design. The displacement measured by the external LVDT includes deformation within the platens (platens 2 and 3), loading nose, and supports, but does not include any deformation occurring within the load frame, load cell, and mounting base (Figure 1). The calibration of the LVDT was verified using gage blocks (Hoke Precision Gage Blocks; Pratt \& Whitney Measurement Systems Inc., Bloomfield, $\mathrm{CT}$ ), while the sensor was mounted onto the jig. The slope of LVDT measurement versus gage block thickness was $0.9980\left(R^{2}=1.0\right)$, indicating an LVDT displacement measurement error of approximately $0.2 \%$.

In the original jig design, the loading nose and supports were $1 / 32$-in $(0.8 \mathrm{~mm})$ diameter stainless steel pins. The compliance of the platens, loading nose and supports, based on the load cell and external LVDT measurements, was assessed using a stiff "dummy specimen" (a 7/32-in stainless steel Allen key). With these thinner pins, the compliance was not constant but instead increased nonlinearly with increasing load. This problem was resolved once these pins were replaced with thicker ones having a 1/16-in $(1.6 \mathrm{~mm})$ diameter. The final compliance of the platen and 1/16-in $(1.6 \mathrm{~mm})$ diameter loading nose and supports, based on the load cell and external LVDT measurements, was $0.06 \mu \mathrm{m} / \mathrm{N}$.

\section{Validation of the three-point bending setup with bovine cortical bone}

A cross-section of cortical bone was harvested from the midfemoral diaphysis of a 1-year-old female cow. Miniature rectangular cortical beams were obtained from this cross-section using a diamond saw (IsoMet ${ }^{\circ}$ Low Speed Saw; Buehler ${ }^{\circledast}$, Lake Bluff, IL) and a 0.3-mm-thick blade. First, the cross-sections were cut into slices, each having a thickness approximately equal to the desired beam depth. The beams were then obtained from these bone slices (Figure 2). The following precautions were taken while cutting the beam specimen. The diamond saw blade was thinner in the periphery, which caused thickness variations in the machined part. More specifically, the last corner of the bone slice to be cut by the diamond saw had a larger thickness than the other regions of the slice (e.g. in one slice, that difference was $27 \%$ ). The region having higher thickness than the rest of the slice 
was identified, marked with a permanent marker, and excluded when machining beams from the slice. The thickness was found to be relatively even within the remaining regions of the slice (after the last-cut thicker corner was removed), with variations of $1 \%-2 \%$. Each beam was machined such that its depth was equivalent to the thickness of the slice. Finally, when machining the beams from the bone slices, the slices were gripped onto a 1/4-in-thick acrylic backing to prevent bending of the slice during cutting.

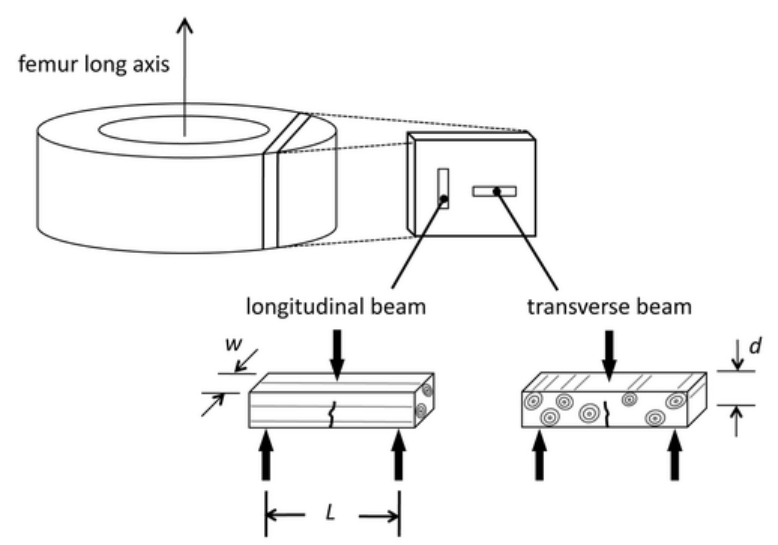

Figure 2. Anatomical orientation and flexural loading configuration for the longitudinal and transverse beams. Dimensions shown are specimen width $(w)$, depth $(d)$, and span length $(L)$.

Three groups of specimens were tested: T1, L1, and L2, each having 13 beam specimens, $\mathrm{n}=13$ (Table 1 ). In group $\mathrm{T} 1$, the beam specimens were machined such that the long beam axis was transverse to the long axis of the femoral diaphysis, whereas in groups $L 1$ and $L 2$, the beam long axis was oriented parallel to the diaphyseal long axis (Figure 2). The beams were at least $5 \mathrm{~mm}$ in length and approximately $1 \mathrm{~mm}$ in width ( $w$ ). A beam depth $(d)$ of approximately $650 \mu \mathrm{m}(L / d$ ratio of approximately 6$)$ was used for groups T1 and L1. For group $\mathrm{L} 2, d$ was approximately $800 \mu \mathrm{m}(L / d$ ratio of approximately 5$)$. The beam $w$ and $d$ measurements were obtained with a digital micrometer (Model 293-340; Mitutoyo Corporation, Kanagawa, Japan). These measurements are shown in Table 1.

Table 1. Beam dimensions and anatomical orientation for each group of bovine bone specimens (median (range)).

\begin{tabular}{|l|l|l|l|l|}
\hline $\begin{array}{l}\text { Beam } \\
\text { group }\end{array}$ & Orientation & $\begin{array}{l}\text { Number } \\
\text { of beams }\end{array}$ & $w(\mathrm{~mm})$ & $d(\mathrm{~mm})$ \\
\hline T1 & Transverse & 13 & 1033 & 683 \\
\hline & & & $(972-1113)$ & $(627-747)$ \\
\hline L1 & Longitudinal & 13 & 973 & 643 \\
\hline & & & $(926-1037)$ & $(636-659)$ \\
\hline L2 & Longitudinal & 13 & 989 & 806 \\
\hline & & & $(875-1088)$ & $(803-815)$ \\
\hline
\end{tabular}

w: beam specimen width; d: beam specimen depth.

The loading was applied using Bluehill 2 Software (Instron $\left.{ }^{\circledR}\right)$ in flexural loading mode. The loading consisted of five cycles of preconditioning followed by a ramp to failure. The preconditioning cycles were applied at a crosshead displacement rate of $0.3 \mathrm{~mm} / \mathrm{min}$ with minimum-maximum loads of $0.05-1.0 \mathrm{~N}$ (<15 MPa) for group $\mathrm{T} 1$ and $0.05-2.0 \mathrm{~N}(<30 \mathrm{MPa})$ for groups $\mathrm{L} 1$ and $\mathrm{L} 2$. The ramp to failure was applied in displacement control, using the external LVDT to control the displacement rate. The LVDT displacement rate was 2 (groups L1 and T1) 
and $1.7 \mathrm{~mm} / \mathrm{min}$ (group L2), which resulted in strain rates of $0.8 \% / \mathrm{s}-1.0 \% / \mathrm{s}$ for all specimens. The specimens were kept hydrated during the test using a drop of normal saline, which was held in place by surface tension.

The force and displacement data were sampled at $100 \mathrm{~Hz}$ throughout the test. The flexural stress and strain were obtained from the load and LVDT displacement data using the following beam equations

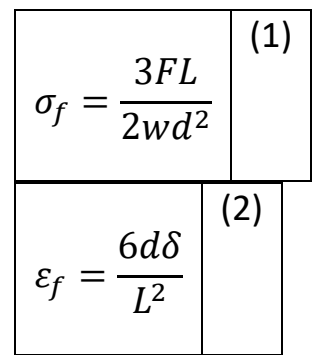

where $I$ is the cross-sectional moment of inertia of the beam; $w$ and $d$ are the beam specimen width and depth, respectively (Figure 2); $L$ is the span between the supports; $F$ is the applied load; $\delta$ is the beam deflection at midspan (displacement measured by the LVDT); and $\sigma_{f}$ and $\varepsilon_{f}$ are the calculated maximum tensile stress and strain at midspan, respectively.

The following material properties were calculated from the stress-strain curve obtained during the displacement ramp to failure. The yield strength $\left(\sigma_{y}\right)$ and yield strain $\left(\varepsilon_{y}\right)$ were determined using the $0.2 \%$ strain offset method (Figure 3). The flexural strength $\left(\sigma_{f m}\right)$ was defined as the maximum stress on the stress-strain curve. The energy absorbed to failure was estimated as the area under the stress-strain curve. The modulus of elasticity $(E)$ was determined using the following equation

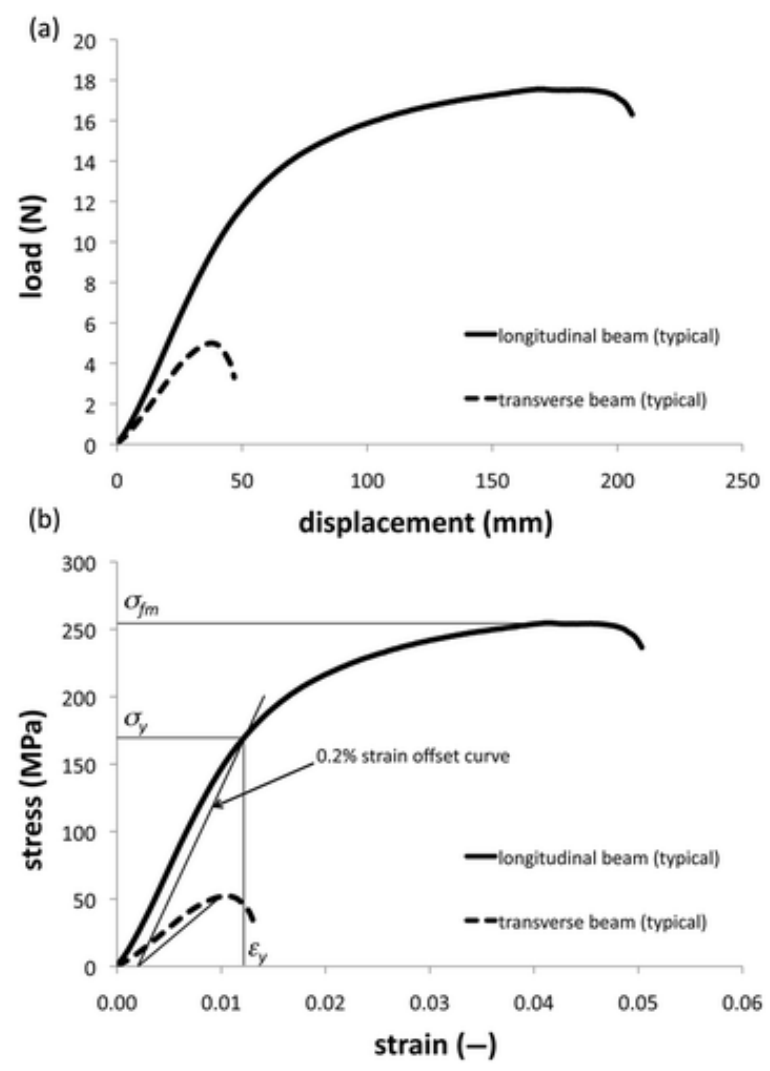

Figure 3. Typical curves for (a) load-displacement and (b) flexural stress-strain data obtained from longitudinal (black) and transverse (gray) beam specimens. Yield strength $\left(\sigma_{y}\right)$ and wield strain $\left(\varepsilon_{y}\right)$ were calculated using the 
$0.2 \%$ strain offset method. Flexural strength $\left(\sigma_{f m}\right)$ was determined as the maximum stress on the flexural stressstrain curve.

$$
E=m \frac{L^{3}}{4 w d^{3}}{ }^{(3)}
$$

where $\mathrm{m}$ is the slope of the straight part of the load-displacement curve. For groups $L 1$ and $L 2, E$ was calculated over a load range equivalent to stresses of 50-100 MPa, while for group $\mathrm{T} 1$, it was calculated within the equivalent stress range of 20-30 MPa.

The flexural properties were compared between groups $\mathrm{L} 1$ and $\mathrm{T} 1$, and between groups $\mathrm{L} 1$ and $\mathrm{L} 2$ using MannWhitney $U$ tests, with a significance level of 0.05 . A nonparametric method was chosen because the normality assumption was rejected in one of the variables $\left(\varepsilon_{y}\right)$ for group T1, based on the Wilks-Shapiro test. For the sake of uniformity, nonparametric statistical approach was used consistently for all analyses, and the median and ranges were reported for all variables.

\section{Validation of the three-point bending setup with acrylic specimens}

The three beams of acrylic were prepared using the same specimen preparation methods as described for the bone specimens. Each beam was tested twice nondestructively, up to a maximum bending stress of approximately $35 \mathrm{MPa}$. The elastic modulus was obtained from the straight part of the stress-strain curve, that is, between stresses of 10 and $35 \mathrm{MPa}$.

\section{Pilot study-osteotomy specimens from two children with OI}

Under Institutional Review Board (IRB) approval and informed consent, two bone specimens were obtained from children with OI during routine osteotomy procedures (IRB \#10101309 from Rush University Medical Center and \#HR-2167 from Marquette University). Specimen "OI-I" was obtained from the right humeral diaphysis of an 11-year-old girl with OI type I (mild form of the disorder), and specimen "OI-III" from the right femoral diaphysis of an 8-year-old female with OI type III (severe form). The specimens were prepared into small beams using the same methods as described for the bovine bone specimens. The specimen OI-I, however, was too small to grip directly with the diamond saw chuck, and therefore, this specimen was affixed onto a wood mandrel using cyanoacrylate prior to cutting. These human bone specimens were oriented such that the long beam axis was parallel to the estimated long bone axis (based on the curvature of the periosteal surface). Their dimensions (Table 2 ) were roughly the same as those in bovine group L1, and they were subjected to the same test methods as described previously for that group.

Table 2. Description of the pediatric Ol bone specimens (median (range)).

\begin{tabular}{|l|l|l|l|l|l|l|l|}
\hline $\begin{array}{l}\text { Human } \\
\text { specimen }\end{array}$ & Ol severity & Age & $\begin{array}{l}\text { Anatomic } \\
\text { site }\end{array}$ & $\begin{array}{l}\text { Beam } \\
\text { orientation }\end{array}$ & $\begin{array}{l}\text { Number } \\
\text { of beams }\end{array}$ & $w(\mathrm{~mm})$ & $d(\mathrm{~mm})$ \\
\hline OI-I & Type I (mild) & 11 & Right femur & Longitudinal & 3 & $\begin{array}{l}1057(1013- \\
1119)\end{array}$ & $\begin{array}{l}593(590- \\
610)\end{array}$ \\
\hline OI-III & $\begin{array}{l}\text { Type III } \\
\text { (severe) }\end{array}$ & 8 & $\begin{array}{l}\text { Right } \\
\text { humerus }\end{array}$ & Longitudinal & 9 & $969(888-1040)$ & $\begin{array}{l}636(617- \\
652)\end{array}$ \\
\hline
\end{tabular}

OI-I: osteogenesis imperfecta type I; OI-III: osteogenesis imperfecta type III.

\section{Results}

The load-displacement curves and corresponding stress-strain curves for typical longitudinal and transverse bovine bone specimens are shown in Figure 3. The stress-strain curves for the beams of $\mathrm{OI}$ bone are presented 
in Figure 4. The flexural material properties for the acrylic, bovine bone and human OI bone specimens are presented in Table 3.

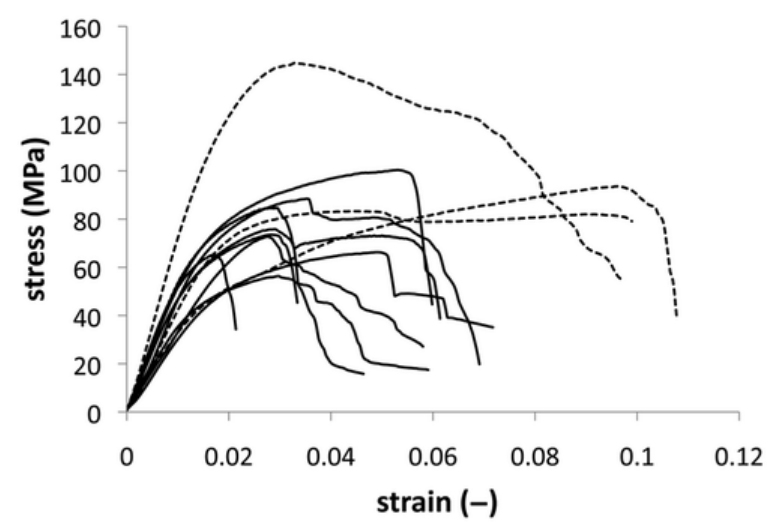

Figure 4. Stress-strain data curves for the OI bone specimens. The three beams obtained from the individual with mild OI (specimen $\mathrm{OI}-\mathrm{I}$ ) are shown as dashed lines, while the nine beams obtained from the individual with severe OI (specimen OI-III) are shown as solid lines.

Table 3. Cortical bone modulus $(E)$, flexural strength $\left(\sigma_{f m}\right)$, yield strength $\left(\sigma_{y}\right)$, yield strain $\left(\varepsilon_{y}\right)$, and energy absorbed to failure measured for the bovine and pediatric OI bone, and acrylic beams (median (range)).

\begin{tabular}{|l|l|l|l|l|l|}
\hline Specimens & $E(\mathrm{GPa})$ & $\mathrm{s}_{f m}(\mathrm{MPa})$ & $\mathrm{s}_{y}(\mathrm{MPa})$ & $\mathrm{e}_{y}(\%)$ & $\begin{array}{l}\text { Energy to } \\
\text { failure }\left(\mathrm{MJ} / \mathrm{m}^{3}\right)\end{array}$ \\
\hline T1 & $6.4(4.7-7.9)$ & $57(43-71)$ & $56(43-63)$ & $1.02(0.91-1.45)$ & $0.53(0.25-1.53)$ \\
\hline L1 & $\begin{array}{l}16.1(14.4- \\
19.3)^{*}\end{array}$ & $251(219-293)^{*}$ & $180(161-225)^{*}$ & $\begin{array}{l}1.36(1.30- \\
1.53)^{*}\end{array}$ & $10.1(6.6-15.2)^{*}$ \\
\hline L2 & $\begin{array}{l}17.3(12.8- \\
19.3)^{* *}\end{array}$ & $\begin{array}{l}308(253- \\
345)^{* * *}\end{array}$ & $\begin{array}{l}258(207- \\
280)^{* * *}\end{array}$ & $\begin{array}{l}1.68(1.51- \\
2.08)^{* * *}\end{array}$ & $\begin{array}{l}19.8(10.5- \\
24.8)^{* * *}\end{array}$ \\
\hline Mild OI (OI-I) & $4.5(3.2-7.4)$ & $94(83-145)$ & $65(46-114)$ & $1.66(1.65-1.73)$ & $7.5(7.2-10.4)$ \\
\hline $\begin{array}{l}\text { Severe OI (OI- } \\
\text { III) }\end{array}$ & $5.1(3.0-5.8)$ & $74(56-100)$ & $57(44-69)$ & $1.43(1.18-2.39)$ & $3.7(0.9-4.7)$ \\
\hline Acrylic & $3.1(3.0-3.1)$ & & & & \\
\hline
\end{tabular}

$* p<0.001$ compared to group T1.

$* * p=0.069$ compared to group L1.

$* * * p<0.001$ compared to group L1.

For the beams of bovine bone, the orientation (T1 vs. L1) had a significant effect on all measured flexural properties $(p<0.001)$. The median $E$ was $60 \%$ lower in the transverse beams (group $T 1$ ) than in the longitudinal beams of equivalent dimensions (group L1). Similarly, the medians $\sigma_{y}, \varepsilon_{y}, \sigma_{f m}$, and energy to failure were $69 \%$, $25 \%, 77 \%$, and $95 \%$ lower, respectively, for the transverse beams than for the longitudinal ones.

When comparing results from groups L1 vs. L2, the following observations were made. There was no significant difference in $E$ between these two groups $(p=0.069)$. However, the beam depth had a significant effect on $\sigma_{y}$, $\varepsilon_{y}, \sigma_{f m}$ and energy to failure ( $p<0.001$ ). The median results for $\sigma_{y}, \varepsilon_{y}, \sigma_{f m}$, and energy to failure were $69 \%, 19 \%$, $19 \%$, and $96 \%$ higher for specimens in group L2 than for those in group L1, respectively. 


\section{Discussion}

In this study, a validated three-point bending test setup is described that enables measuring flexural bone material properties of small cortical osteotomy specimens. The test method was validated using miniature beams of acrylic, as well as beams of bovine cortical bone oriented longitudinally and transversely relative to the long axis of the femur diaphysis. Finally, a pilot study of osteotomy specimens from children with Ol was performed, providing the first data for bone material strength in this patient population.

Three point bending tests are a common tool used to characterize bone material properties. ${ }^{1,16,23-}$

${ }^{25}$ Nonetheless, these bending tests entail a number of limitations. For example, local deformation of the specimen is likely to occur at the points of contact with the loading nose and supports due to stress concentrations. This local deformation can result in an overestimation of beam deflection at midspan, and thus underestimation of $E$. Fracture is assumed to occur at the midpoint between the supports, which may not be exactly true. Furthermore, the beam theory used to derive stresses and strains from the load-displacement data assumes linear elastic behavior throughout the test. This assumption, however, does not hold true beyond the point of yield. For this reason, bending test results tend to overestimate ultimate material strength. A more indepth discussion of this phenomenon can be found in previous works. ${ }^{26,27}$ To emphasize its distinction from ultimate tensile strength, the maximum stress value in bending is sometimes referred to as "flexural strength," 28 "bending strength," "'modulus of rupture," ${ }^{29,30}$ or "computed ultimate bending strength." ${ }^{2}$ In this article, this value is reported as flexural strength. Similarly, the energy to failure was calculated for each bone specimen as the area under the flexural stress-strain curve up to the point of fracture. Due to overestimation of stress in the post-yield region, the energy to failure results presented in this study thus represent estimates rather than accurate values.

A minimum span/depth aspect ratio of 8 has been recommended for measuring the flexural properties of ceramic materials (ASTM C674). For bone, $E$ has been found to decrease with decreasing span/depth ratio when that ratio was below 15 , while it was roughly constant for ratio over $20 .{ }^{31}$ As mentioned earlier, due to the small size of our previously collected pediatric bone specimens, a maximum span length of $4 \mathrm{~mm}$ was deemed appropriate for characterizing those specimens. With this chosen span length, beam depths of 500 and $266 \mu \mathrm{m}$ would be required in order to obtain span/depth ratios of 8 and 15, respectively. As discussed earlier, the beam depths above $560 \mu \mathrm{m}$ (i.e. span/length ratios of 5 and 6) were selected for our specimens on the basis of decreased $E$ values reported with smaller beam depths. ${ }^{16}$ This minimum depth value, being two or three times the size of a secondary osteon, also ensures a certain amount of heterogeneity in microstructure within the specimens. Nonetheless, it should be acknowledged that the relatively small span/depth aspect ratios used in this study may have resulted in some error due to shear deformation within the specimens. ${ }^{31,32}$

In spite of the abovementioned limitations, the methods described in this article yielded reasonable results for acrylic as well as bovine bone. For acrylic, $E$ was within $3 \%$ of the expected value of $3.2 \mathrm{MPa} .{ }^{33} \mathrm{The}$ longitudinal $E$ values for bovine bone (groups L1 and L2) were of similar magnitude to those reported in another bending study that characterized larger bovine specimens $(10 \mathrm{~mm} \times 4 \mathrm{~mm} \times 80 \mathrm{~mm})$, that is, $18.6 \pm$ $1.2 \mathrm{GPa} .{ }^{25}$ Similarly, the longitudinal $\sigma_{f m}$ results were within the range of value reported in other studies of larger bovine bone specimens in bending, that is, 170-400 MPa. ${ }^{3,25}$

In this study, beam depth did not have a significant effect on longitudinal $E$. There was no significant difference in $E$ between groups $L 1$ and L2, having specimen depths of 636-659 $\mu \mathrm{m}$ (span/depth ratio of 6) and 803-815 $\mu \mathrm{m}$ (ratio of 5), respectively. This observation was similar to that of a previous study of human cortical bone, in which a more or less constant $E$ was reported for beam depths greater than $560 \mu \mathrm{m}$, with a constant span/depth ratio of $10 .{ }^{16}$ Beam depth, however, had significant effects on $\sigma_{y}, \varepsilon_{f y}$, and $\sigma_{f m}$, all of which were higher for the thicker specimens (group L2) than for the thinner ones (L1). 
Micromechanical bending studies of human bone, ${ }^{14-16}$ with specimen depths ranging from 50 to $200 \mu \mathrm{m}$, reported much lower $E$ (by 50\%-75\%) than typical values for larger adult human cortical bone specimens (15$20 \mathrm{GPa}){ }^{4,22}$ This size-related phenomenon has not yet been explained, however, it was suggested that the lower $E$ reported in micromechanical bending tests may be attributed to stress concentrations and inhomogeneities in microspecimens caused by Haversian canals and canaliculi. ${ }^{34}$ The methods described in this article, however, did not result in such underestimation of $E$, but provided values similar to those reported for larger bovine bone specimens. ${ }^{25}$

The methods described in this article were used to characterize two osteotomy specimens from children with OI. For these specimens, $E$ was lower than values previously obtained by nanoindentation for children with severe OI (9-22) GPa. ${ }^{10-13,18}$ The moduli measured by nanoindentation, however, do not take into account specimen porosity, and a substantial amount of cortical porosity was apparent in our specimens by visual inspection. Such cortical porosity has also been observed histologically in iliac biopsies from children with $0 \mathrm{I} .{ }^{35}$ In the pediatric OI specimens observed in this study, the flexural properties were lower than previously published values for adult cortical bone, for example, 11-20 GPa for $E, 194$ (21) MPa for $\sigma_{f m}$, and 154 (13) MPa for $\sigma_{y}{ }^{4,22,23}$ Little normal pediatric data, unfortunately, is available for comparison with the flexural properties measured in this study. One study characterized flexural properties in cadaveric bones from children and adults. ${ }^{6}$ It was found that $E$ and $\sigma_{f m}$ were lower in pediatric than in adult bones. The $E$ values reported in that study (79-162 GPa, when combining specimens of all ages), however, were consistently much higher than the generally accepted range for adult human bones. The flexural strength for the two Ol pediatric bone specimens were lower than the value previously reported for a "normal" 8-year-old girl (190 MPa). ${ }^{6}$ This apparent decreased flexural strength in the pediatric Ol bone specimens may be the result of cortical porosity.

In this study, the beams obtained from the individual with severe OI (specimen OI-III) absorbed less energy to failure than did those obtained from the individual with mild OI (specimen OI-I). Nonetheless, a certain amount of variability was seen within each OI osteotomy specimen (Table 3 and Figure 4), and in light of the small sample size in this pilot study (one specimen with each mild and severe OI), a larger study is needed to draw definitive conclusions regarding the effects of $\mathrm{Ol}$ severity on bone material properties.

In conclusion, this study describes a validated three-point bending test method with a span of $4 \mathrm{~mm}$ suitable to characterize the material behavior of miniature bone specimens such as those obtained during osteotomy procedures. This method provided reasonable $E, \sigma_{y}$, and $\sigma_{f m}$ results for bovine bone. The results for $\sigma_{y}$, and $\sigma_{f m}$, however, were sensitive to the span/depth aspect ratio. For that reason, this parameter should be considered when comparing bone properties measured with the presented method. Two specimens obtained from children with Ol were also characterized in a pilot study, providing the first ever data for flexural and yield strength for this patient population. Finally, the flexural test setup described in this article can be used to characterize miniature bone specimens, such as those obtained during routine osteotomy procedures, which can lead to improved understanding of bone disorders such as OI.

\section{Appendix 1}

\section{Notations}

$d$ beam specimen depth

$E$ modulus of elasticity

F applied load

I cross-sectional moment of inertia of the beam specimen

$L$ span length between the supports

$m$ slope of load-displacement curve in the linear elastic region 
Ol osteogenesis imperfecta

$w$ beam specimen width

$\delta$ beam deflection at midspan

$\varepsilon_{f}$ maximum tensile strain at midspan

$\varepsilon_{y}$ yield strain

$\sigma_{f}$ maximum tensile stress at midspan

$\sigma_{f m}$ flexural strength

$\sigma_{y}$ yield strength

\section{Acknowledgements}

The authors wish to thank Thomas Silman, Ray Hamilton, and Dave Gibas from the Discovery Learning Laboratory at Marquette University for their help in designing and machining the testing apparatus. We are also grateful to Dr. Peter Smith, Pediatric Surgeon at Shriners Hospitals for Children, Chicago, for his support and for providing the pediatric bone specimens used in this study, as well as to Ms Kathy Reiners, Motion Analysis Laboratory Coordinator at Shriners Hospitals for Children, Chicago, for her assistance with collection and handling of those specimens.

\section{Funding}

The contents of this article were developed under a grant from the Department of Education, NIDRR grant H133E100007. However, these contents do not necessarily represent the policy of the Department of Education, and you should not assume endorsement by the Federal Government.

\section{Conflict of interest}

The authors report no conflicts of interest. This work was supported by the U.S. Department of Education NIDRR grant H133P080005.

\section{References}

\begin{tabular}{|c|c|}
\hline 1. & th of compact bone? J Exp Biol 1999; 2 \\
\hline 2. & $\begin{array}{l}\text { Draper, ER, Goodship, AE. A novel technique for four-point bending of small bone samples with semi- } \\
\text { automatic analysis. J Biomech 2003; 36: 1497-1502. }\end{array}$ \\
\hline 3. & $\begin{array}{c}\text { Kemper, N, Davison, N, Fitzpatrick, D. Characterization of the mechanical properties of bovine cortical } \\
\text { bone treated with a novel tissue sterilization process. Cell Tissue Bank 2010; } 12: 273-279 .\end{array}$ \\
\hline 4. & $\begin{array}{l}\text { Reilly, DT, Burstein, AH. The elastic and ultimate properties of compact bone tissue. J Biomech 1975; } \\
\text { 8: 393-405. }\end{array}$ \\
\hline 5. & $\begin{array}{l}\text { Zioupos, P, Currey, JD. Changes in the stiffness, strength, and toughness of human cortical bone with } \\
\text { age. Bone 1998; 22: 57-66. }\end{array}$ \\
\hline 6. & $\begin{array}{l}\text { Currey, JD, Butler, G. The mechanical properties of bone tissue in children. J Bone Joint Surg Am 1975; } \\
\text { 57: 810-814. }\end{array}$ \\
\hline 7. & $\begin{array}{l}\text { Ohman, C, Baleani, M, Pani, C. Compressive behaviour of child and adult cortical bone. Bone 2011; } \\
\text { 49: 769-776. }\end{array}$ \\
\hline 8. & $\begin{array}{l}\text { Fritz, JM, Guan, Y, Wang, M. A fracture risk assessment model of the femur in children with osteogenesis } \\
\text { imperfecta (OI) during gait. Med Eng Phys 2009; 31: 1043-1048. }\end{array}$ \\
\hline 9. & $\begin{array}{l}\text { Fritz, JM, Guan, Y, Wang, M. Muscle force sensitivity of a finite element fracture risk assessment model } \\
\text { in osteogenesis imperfecta-biomed 2009. Biomed Sci Instrum 2009; 45: 316-321. }\end{array}$ \\
\hline 10. & $\begin{array}{l}\text { Fan, Z, Smith, PA, Eckstein, EC. Mechanical properties of OI type III bone tissue measured by } \\
\text { nanoindentation. J Biomed Mater Res A 2006; 79: 71-77. }\end{array}$ \\
\hline
\end{tabular}




\begin{tabular}{|c|c|}
\hline 11. & $\begin{array}{l}\text { Fan, Z, Smith, PA, Harris, GF. Comparison of nanoindentation measurements between osteogenesis } \\
\text { imperfecta Type III and Type IV and between different anatomic locations (femur/tibia vs. iliac } \\
\text { crest). Connect Tissue Res } 2007 ; 48: 70-75 \text {. }\end{array}$ \\
\hline 12. & $\begin{array}{l}\text { Fan, Z, Smith, PA, Rauch, F. Nanoindentation as a means for distinguishing clinical type of osteogenesis } \\
\text { imperfecta. Compos Part B: Eng 2007; 38: 411-415. }\end{array}$ \\
\hline 13. & $\begin{array}{l}\text { Weber, M, Roschger, P, Fratzl-Zelman, N. Pamidronate does not adversely affect bone intrinsic material } \\
\text { properties in children with osteogenesis imperfecta. Bone 2006; 39: 616-622. }\end{array}$ \\
\hline 14. & $\begin{array}{l}\text { Kuhn, JL, Goldstein, SA, Choi, K. Comparison of the trabecular and cortical tissue moduli from human } \\
\text { iliac crests. J Orthop Res 1989; 7: 876-884. }\end{array}$ \\
\hline 15. & $\begin{array}{l}\text { Choi, K, Goldstein, SA. A comparison of the fatigue behavior of human trabecular and cortical bone } \\
\text { tissue. J Biomech 1992; 25: 1371-1381. }\end{array}$ \\
\hline 16. & $\begin{array}{l}\text { Choi, K, Kuhn, JL, Ciarelli, MJ. The elastic moduli of human subchondral, trabecular, and cortical bone } \\
\text { tissue and the size-dependency of cortical bone modulus. J Biomech 1990; 23: 1103-1113. }\end{array}$ \\
\hline 17. & $\begin{array}{l}\text { Guo, XE, Goldstein, SA. Vertebral trabecular bone microscopic tissue elastic modulus and hardness do } \\
\text { not change in ovariectomized rats. J Orthop Res } 2000 ; 18: 333-336 .\end{array}$ \\
\hline 18. & $\begin{array}{l}\text { Albert, C, Jameson, J, Toth, J. Intrinsic modulus of bone in osteogenesis imperfecta-a nanoindentation } \\
\text { study. In: 17th Biennial Canadian Society for Biomechanics Conference, CSB-SCB } 2012 \\
\text { Presentations Program, Simon Fraser University website (http://ocs.sfu.ca/csb-scb/index.php/csb- } \\
\text { scb/2012), Burnaby, BC, Canada, June 6-9, } 2012 \text {. }\end{array}$ \\
\hline 19. & $\begin{array}{l}\text { Hoffler, CE, Guo, XE, Zysset, PK. An application of nanoindentation technique to measure bone tissue } \\
\text { lamellae properties. J Biomech Eng 2005; 127: 1046-1053. }\end{array}$ \\
\hline 20. & $\begin{array}{l}\text { Rho, JY, Pharr, GM. Effects of drying on the mechanical properties of bovine femur measured by } \\
\text { nanoindentation. J Mater Sci Mater Med 1999; 10: 485-488. }\end{array}$ \\
\hline 21. & $\begin{array}{l}\text { Rho, JY, Zioupos, P, Currey, JD. Microstructural elasticity and regional heterogeneity in human femoral } \\
\text { bone of various ages examined by nano-indentation. J Biomech 2002; 35: 189-198. }\end{array}$ \\
\hline 22. & $\begin{array}{l}\text { Currey, JD . Mechanical properties of vertebrate hard tissues. Proc IMechE, Part H: J Engineering in } \\
\text { Medicine 1998; 212: 399-411. }\end{array}$ \\
\hline 23. & $\begin{array}{l}\text { Wang, X, Bank, RA, TeKoppele, JM. The role of collagen in determining bone mechanical properties. J } \\
\text { Orthop Res 2001; 19: 1021-1026. }\end{array}$ \\
\hline 24. & $\begin{array}{l}\text { Nyman, JS, Roy, A, Shen, X. The influence of water removal on the strength and toughness of cortical } \\
\text { bone. J Biomech 2006; 39: 931-938. }\end{array}$ \\
\hline 25. & $\begin{array}{l}\text { Martin, RB, Boardman, DL. The effects of collagen fiber orientation, porosity, density, and mineralization } \\
\text { on bovine cortical bone bending properties. J Biomech 1993; 26: 1047-1054. }\end{array}$ \\
\hline 26. & $\begin{array}{l}\text { Burstein, AH, Currey, JD, Frankel, VH. The ultimate properties of bone tissue: the effects of yielding. J } \\
\text { Biomech 1972; 5: 35-44. }\end{array}$ \\
\hline 27. & Currey, J . Bones: structure and mechanics. 2nd ed. Princeton, NJ: Princeton University Press, 2002. \\
\hline 28. & $\begin{array}{l}\text { ASTM-D790-07. Standard methods for flexural properties of unreinforced and reinforced plastics and } \\
\text { electrical insulating materials. West Conshohocken, PA: ASTM International, } 2006 .\end{array}$ \\
\hline 29. & $\begin{array}{l}\text { Young, WC, Budynas, RG. Roark's formulas for stress and strain. 7th ed. McGraw-Hill, New York, } \\
\text { NY, } 2002 .\end{array}$ \\
\hline 30. & $\begin{array}{l}\text { ASTM-C674-88. Standard test methods for flexural properties of ceramic whiteware materials. West } \\
\text { Conshohocken, PA: ASTM International, } 2006 \text {. }\end{array}$ \\
\hline 31. & $\begin{array}{l}\text { Spatz, HC, O'Leary, EJ, Vincent, JF. Young's moduli and shear moduli in cortical bone. Proc Biol Sci 1996; } \\
\text { 263: 287-294. }\end{array}$ \\
\hline 32. & $\begin{array}{l}\text { Schriefer, JL, Robling, AG, Warden, SJ. A comparison of mechanical properties derived from multiple } \\
\text { skeletal sites in mice. J Biomech } 2005 ; 38: 467-475 .\end{array}$ \\
\hline 33. & $\begin{array}{l}\text { McCrum, NG, Buckley, CP, Bucknall, CB. Principles of polymer engineering. 2nd ed. Oxford University } \\
\text { Press, New York, NY, } 1997 .\end{array}$ \\
\hline 34. & Turner, CH, Burr, DB. Basic biomechanical measurements of bone: a tutorial. Bone 1993; 14: 595-608. \\
\hline
\end{tabular}


35. Rauch, F, Travers, R, Parfitt, AM. Static and dynamic bone histomorphometry in children with osteogenesis imperfecta. Bone 2000; 26: 581-589. 